\title{
Carbon mineralization in Arctic sediments northeast of Svalbard: Mn(IV) and Fe(III) reduction as principal anaerobic respiratory pathways
}

\author{
Verona Vandieken $^{1,2, *}$, Maren Nickel ${ }^{1}$, Bo Barker Jørgensen ${ }^{1}$ \\ ${ }^{1}$ Max Planck Institute for Marine Microbiology, Celsiusstrasse 1, 28359 Bremen, Germany \\ ${ }^{2}$ Present address: Exobiology Branch, NASA Ames Research Center, Mail Stop 239-4, Moffet Field, California 94035-1000, USA
}

\begin{abstract}
Carbon oxidation rates and pathways were determined in 3 sediments at latitude $79^{\circ}$ to $81^{\circ} \mathrm{N}$ in the Barents Sea, where the ice cover restricts primary production to a few months of the year. Oxygen uptake $\left(1.5\right.$ to $\left.3.5 \mathrm{mmol} \mathrm{m}^{-2} \mathrm{~d}^{-1}\right)$ and sulfate reduction $\left(<0.1\right.$ to $0.22 \mathrm{mmol} \mathrm{m}^{-2} \mathrm{~d}^{-1}$ over 0 to $10 \mathrm{~cm}$ depth) rates were measured by whole core incubation. Pathways of anaerobic carbon oxidation were determined by combining results of anoxic sediment bag incubations with pore water and solid phase analyses of the sediments. In accordance with the high contents of solid Mn $(\geq 60 \mu \mathrm{mol}$ $\mathrm{cm}^{-3}$ ) and Fe(III) $\left(\geq 108 \mu \mathrm{mol} \mathrm{cm}{ }^{-3}\right)$, dissimilatory Mn(IV) and Fe(III) reduction contributed between 69 and $\geq 90 \%$ to anaerobic carbon mineralization in the upper $10 \mathrm{~cm}$ of the sediments. At 2 of the 3 stations, sulfate reduction rates were below our detection limit of $1 \mathrm{nmol} \mathrm{cm}^{-3} \mathrm{~d}^{-1}$. Solid $\mathrm{Mn}$ and Fe(III) were abundant from the surface to $10 \mathrm{~cm}$ sediment depth and were apparently the only important anaerobic electron acceptors. At the third station, vertical zonation of anaerobic mineralization was observed, with $\mathrm{Mn}(\mathrm{IV})$ reduction at 0 to $3 \mathrm{~cm}$ followed by concurrent Fe(III) and sulfate reduction at 3 to $5 \mathrm{~cm}$ and sulfate reduction at 5 to $10 \mathrm{~cm}$. Rates of microbial carbon oxidation were low compared to those in fjords on the west and south coasts of Svalbard. This is in accordance with the limited organic carbon supply by primary and secondary productivity caused by long periods of ice coverage.
\end{abstract}

KEY WORDS: Microbial Mn(IV) - Fe(III) reduction · Carbon mineralization · Arctic sediments · Barents Sea $\cdot$ Sediment incubations

\section{INTRODUCTION}

Benthic microbial communities in sediments around Svalbard in the Arctic Ocean experience permanently low temperature, whereas the flux of organic matter to the sea floor varies seasonally. Phytoplankton productivity depends on the short ice-free periods in the summer when light is available for photosynthesis (Hebbeln \& Wefer 1991, Wassmann \& Slagstad 1993). The west and south coasts of Svalbard are influenced by the relatively warm Atlantic water of the West Spitsbergen Current that flows northwards and keeps the coast ice-free most of the year. The north and east coasts, where this study was done, are characterized by cold polar water from the Arctic Ocean, resulting in a later seasonal thawing of the sea ice. Correspondingly, primary production is significantly lower in areas influenced by polar waters and long periods of ice coverage than in areas influenced by Atlantic water (Wassmann \& Slagstad 1993, Sakshaug 1997). The differences in primary production are reflected in higher organic carbon contents and oxygen uptake rates of sediments southwest of Svalbard compared to sediments off the northeast coast (Hulth et al. 1994, 1996).

As the fjord sediments along the south and west coasts of Svalbard are characterized by relatively high organic 
carbon deposition (Eilertsen et al. 1989), mineralization rates are as high as in comparable temperate environments (Arnosti et al. 1998, 2005, Sagemann et al. 1998, Thamdrup \& Fleischer 1998, Kostka et al. 1999). In these Arctic sediments, as well as in sediments along the east coast of Greenland, dissimilatory Fe(III) and sulfate reduction were found to be important terminal, electron accepting pathways for anaerobic carbon oxidation (Rysgaard et al. 1998, Kostka et al. 1999, Glud et al. 2000). Studies on a wide range of coastal marine sediments have shown that Fe reduction is important for carbon oxidation, whereas microbial $\mathrm{Mn}$ reduction is in general insignificant due to low Mn oxide concentrations and to shallow depth distribution of Mn(IV) (Thamdrup 2000). As an exception, dissimilatory Mn reduction was found to be quantitatively important for benthic carbon mineralization in sediments of the Skagerrak, the Panama Basin and the Black Sea due to high Mn oxide contents and high rates of bioturbation (Aller 1990, Canfield et al. 1993a,b, Thamdrup et al. 2000).

This study was part of the Norwegian CABANERA (carbon flux and ecosystem feed back in the northern Barents Sea in an era of climate change) project with the primary goal of understanding how productivity and carbon flux in the Arctic Ocean may change as a result of global warming. Models predict that, within 50 to $60 \mathrm{yr}$, much of the Arctic Ocean will become icefree during summer (ACIA 2004), resulting in dramatic shifts in productivity, communities and carbon flux (McGowan et al. 1998, Anderson \& Piatt 1999). Little is known about how Arctic benthic ecosystems will respond to increased organic fluxes and how this might affect the balance between the main mineralization processes. A comparative study of sediment processes in the Arctic controlled by short ice-free summers northeast of Svalbard and longer ice-free summers along the southwest coast of Svalbard was therefore initiated. The southwest areas were studied during earlier research cruises by Kostka et al. (1999) and Vandieken et al. (2006, this volume). We present here, for the first time, data on pathways of microbial respiration in sediments northeast of Svalbard. The sediments have high concentrations of particulate Mn and Fe(III) and low organic carbon deposition. Rates of $\mathrm{Mn}, \mathrm{Fe}$ and sulfate reduction were determined in relation to the distribution of $\mathrm{Mn}$ and $\mathrm{Fe}$ in the solid phase. The present study shows that, besides aerobic respiration, $\mathrm{Mn}(\mathrm{IV})$ and $\mathrm{Fe}(\mathrm{III})$ reduction are most important for carbon mineralization in the sediments.

\section{MATERIALS AND METHODS}

Sampling sites. Sediments were sampled during the second CABANERA cruise from 20 July to 3 August 2004 on board the RV 'Jan Mayen' off the northeast coast of Nordaustlandet. An overview of the locations and characteristics of the benthic stations are given in Fig. 1 \& Table 1. Stns VIII and XII were located in trenches and were ice-free at the time of sampling. Stn $\mathrm{X}$ was positioned in an area with melting ice floes and was coupled to a pelagic sampling station in the CABANERA project. The sediments of Stns VIII and X were sampled with a multiple corer that retrieved up to 4 cores of $10 \mathrm{~cm}$ inner diameter. At Stn XII, sediment was subsampled from a $50 \mathrm{~cm} \times 50 \mathrm{~cm}$ box core into the cores of the multiple corer.

Anoxic bag incubations. Sediment from the upper $10 \mathrm{~cm}$ of the cores was sliced into the following depth intervals: Stn VIII 0-3 and 6-12 cm, Stns X and XII $0-1,1-2,2-3,3-4,4-5,5-7$ and $7-10 \mathrm{~cm}$. Sediment from the same depth interval of several cores was filled under a constant stream of $\mathrm{N}_{2}$ into gastight plastic bags outdoors at an air temperature of around $0^{\circ} \mathrm{C}$. The incubation bags were closed (without gas phase) and incubated near in situ temperature at $0^{\circ} \mathrm{C}$ inside larger, $\mathrm{N}_{2}$-filled plastic bags to ensure anoxia. Over a period of 55 to $60 \mathrm{~d}$ incubation, subsamples were withdrawn 10 times from each bag, in a cold room $\left(4^{\circ} \mathrm{C}\right)$.

Pore-water and solid phase sampling. Pore water of whole cores and pore water from the bags was retrieved by a pore water press under $\mathrm{N}_{2}$ through GF/F filters. Pore water was filtered directly into Ferrozine-solution to measure $\mathrm{Fe}^{2+}$ (see later subsection). We collected $1.8 \mathrm{ml}$ aliquots for dissolved inorganic

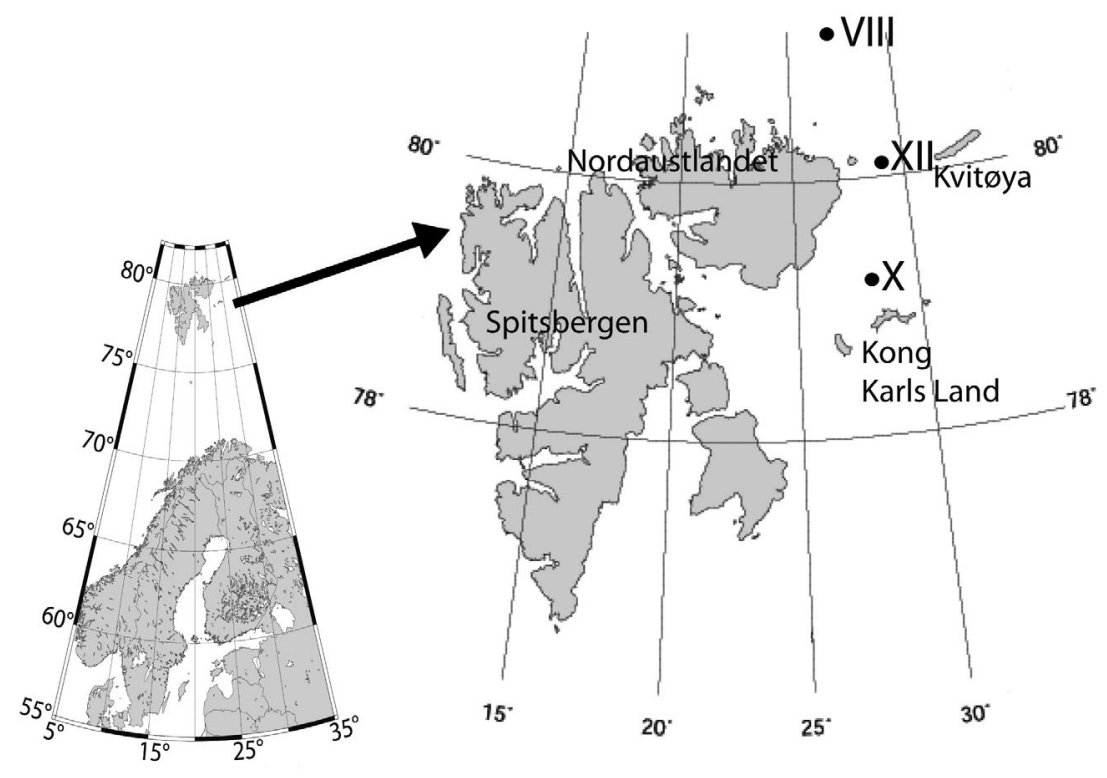

Fig. 1. Sampling stations NE of Svalbard (see Table 1 for details) 
Table 1. Sample site information and sediment characteristics at 3 stations (VIII X, XIII) from 20 July to 3 August 2004. Data are for whole core incubations. $\mathrm{O}_{2}: \mathrm{O}_{2}$ consumption rate; SSR: sulfate reduction rate $(0-10 \mathrm{~cm})$

\begin{tabular}{|c|c|c|c|}
\hline Description & $\begin{array}{l}\text { VIII } \\
\begin{array}{c}\text { Northern Kvitøya } \\
\text { trench }\end{array}\end{array}$ & $\begin{array}{c}\text { X } \\
\text { North of } \\
\text { Kong Karls Land }\end{array}$ & $\begin{array}{c}\text { XII } \\
\text { Central Kvitøya } \\
\text { Trench }\end{array}$ \\
\hline Latitude & $81^{\circ} 16.65^{\prime} \mathrm{N}$ & $79^{\circ} 26.50^{\prime} \mathrm{N}$ & $80^{\circ} 09^{\prime} \mathrm{N}$ \\
\hline Longitude & $26^{\circ} 51.18^{\prime} \mathrm{E}$ & $28^{\circ} 48.43^{\prime} \mathrm{E}$ & $29^{\circ} 36^{\prime} \mathrm{E}$ \\
\hline Water depth (m) & 503 & 303 & 286 \\
\hline Bottom-water temperature $\left({ }^{\circ} \mathrm{C}\right)$ & 2.9 & 2.5 & 2.3 \\
\hline Total organic carbon (\%) & 1.46 & 1.41 & 1.45 \\
\hline Total organic nitrogen (\%) & 0.17 & 0.17 & 0.18 \\
\hline $\mathrm{O}_{2}\left(\mathrm{mmol} \mathrm{m}^{-2} \mathrm{~d}^{-1}\right)$ & $2.1 \pm 0.7$ & $1.5 \pm 0.4$ & $3.5 \pm 1.6$ \\
\hline $\operatorname{SRR}\left(\mathrm{mmol} \mathrm{m}^{-2} \mathrm{~d}^{-1}\right)$ & $<0.1$ & $<0.1$ & $0.22 \pm 0.11$ \\
\hline
\end{tabular}

carbon (DIC) and alkalinity analyses in glass vials without headspace and capped with Viton septa; these were fixed with $\mathrm{HgCl}_{2}$, and stored at $4^{\circ} \mathrm{C}$ until analysis. We froze $1.5 \mathrm{ml}$ of pore water for $\mathrm{NH}_{4}{ }^{+}, \mathrm{NO}_{3}{ }^{-}$ and $\mathrm{NO}_{2}^{-}$analysis. For $\mathrm{Mn}^{2+}$ and $\mathrm{Ca}^{2+}$ determination, $0.5 \mathrm{ml}$ was acidified with $6 \mathrm{M} \mathrm{HCl}$ and stored at $4^{\circ} \mathrm{C}$. Pore water for sulfate and sulfide analyses was preserved with $\mathrm{Zn}$ acetate or $\mathrm{ZnCl}_{2}$. Bottom water from the stations was stored frozen for determination of $\mathrm{NH}_{4}{ }^{+}, \mathrm{NO}_{3}{ }^{-}$and $\mathrm{NO}_{2}{ }^{-}$and (acidified with $\mathrm{HCl}$ ) for $\mathrm{Mn}^{2+}$ analysis.

For the extraction of solid phase Fe and Mn with dithionite and for the determination of total organic $\mathrm{C}$ and $\mathrm{N}$, subsamples were stored frozen at $-21^{\circ} \mathrm{C}$. For the analysis of elemental sulfur, a subsample of 0.5 to 2 g sediment was mixed with $2 \mathrm{ml} 20 \% \mathrm{Zn}$ acetate and stored frozen at $-21^{\circ} \mathrm{C}$.

Pore water analyses. DIC was analyzed by flowinjection with conductivity detection (Hall \& Aller 1992). Fe(II) was measured spectrophotometrically with Ferrozine $\left(1 \mathrm{~g} \mathrm{l}^{-1}\right.$ in $50 \mathrm{mM}$ HEPES buffer, $\left.\mathrm{pH} 7\right)$ at $562 \mathrm{~nm}$ (Dr. Lange LP2W) (Stookey 1970). $\mathrm{NH}_{4}{ }^{+}$was determined spectrophotometrically at $630 \mathrm{~nm}$ (Shimadzu UV 1202) (Grasshoff et al. 1999). $\mathrm{NO}_{3}{ }^{-}$and $\mathrm{NO}_{2}{ }^{-}$ were measured using an $\mathrm{NO}_{\mathrm{x}}$-analyzer (Thermo Environmental Instruments) (Braman \& Hendrix 1989). $\mathrm{Ca}^{2+}$ and $\mathrm{Mn}^{2+}$ in pore water were measured by inductivelycoupled plasma atomic-emission spectrometry (Perkin Elmer Optima 3300 RL). Sulfate was measured by nonsuppressed ion chromatography (Waters, Column IC$\left.\mathrm{Pak}^{\mathrm{TM}}, 50 \times 4.6 \mathrm{~mm}\right)$. Sulfide was determined by the methylene blue spectrophotometric method at $670 \mathrm{~nm}$ (Shimadzu, UV 1202) (Cline 1969). Alkalinity was determined by Gran titration using $0.02 \mathrm{M} \mathrm{HCl}$.

Solid phase analyses. Fe was extracted by $\mathrm{HCl}(0.5 \mathrm{M}$ $\mathrm{HCl}$ for $1 \mathrm{~h}$ ) and the extract analyzed for Fe(II) with Ferrozine and for total Fe with Ferrozine plus $1 \%$ (w/v) hydroxylamine hydrochloride. Fe(III) concentrations were calculated by subtracting concentrations of Fe(II) from total Fe concentrations. Solid Mn in the sediment was quantified after freeze drying and extraction with dithionite-citrate-acetic acid (Canfield 1989) by flame atomic absorption spectrometry (Perkin Elmer, Atomic Absorption Spectrometer 3110). Freeze dried samples for determination of total organic $\mathrm{C}$ and $\mathrm{N}$ contents were pretreated with $\mathrm{HCl}$, dried again, and analyzed using a CNS analyzer (Fisons $^{\mathrm{TM}}$ Na1500 elemental analyzer). For elemental sulfur analysis, a subsample of the sediment frozen in $\mathrm{Zn}$ acetate was extracted with $5 \mathrm{ml}$ methanol (Zopfi et al. 2004). With a Zorbax ODS column $(125 \times 4 \mathrm{~mm}, 5 \mu \mathrm{m}$; Knauer), using methanol as eluent, the sulfur was determined by HPLC from absorption at $265 \mathrm{~nm}$ (detection limit $1 \mu \mathrm{M}$ ).

Sulfate reduction rates. Sulfate reduction rates were measured in 3 parallel cores of $3 \mathrm{~cm}$ diameter each using the ${ }^{35} \mathrm{SO}_{4}{ }^{2-}$ whole core injection technique (Jørgensen 1978). Sulfate reduction in the anoxic bags was determined at each sampling time point in subsamples incubated with $100 \mathrm{kBq}{ }^{35} \mathrm{SO}_{4}{ }^{2-}$ radiotracer in $5 \mathrm{ml}$ glass tubes. After $6 \mathrm{~h}$, the incubations were stopped with $20 \% \mathrm{Zn}$ acetate. Total reduced inorganic sulfur was analyzed by cold chromium distillation (Kallmeyer et al. 2004).

Oxygen consumption rates. Sediment cores with an inner diameter of $54 \mathrm{~mm}$ were closed (without gas phase) with rubber stoppers. The cores were incubated in the dark at $0^{\circ} \mathrm{C}$ with continuous stirring of the water column by a magnetic stirring bar at the top of the water column. Oxygen consumption of the sediment was measured during the whole incubation with a micro-optode (Holst et al. 1997). The volume of the water column was determined by addition of a $\mathrm{NaBr}$ solution. Concentrations of $\mathrm{NaBr}$ were analyzed by anion chromatography (Dionex DX500; eluent: $9 \mathrm{mM}$ $\mathrm{NaCO}_{3}$ i precolumn: AG9 $\mathrm{HC}$; column: AS9 HC). Total oxygen consumption rates were calculated from duplicate cores for Stn VIII, and triplicates for Stns X and XII.

Calculations. The precipitation of $\mathrm{CaCO}_{3}$ during bag incubations was calculated according to Thamdrup et al. (2000) from decreasing $\mathrm{Ca}^{2+}$ concentrations: $\Delta \mathrm{CaCO}_{3}=\Delta\left[\mathrm{Ca}^{2+}\right]_{\mathrm{sol}}\left(1+K_{\mathrm{Ca}}\right)$, where $K_{\mathrm{Ca}}$ is the adsorption constant for $\mathrm{Ca}^{2+}\left(K_{\mathrm{Ca}}=1.6\right)$ (Li \& Gregory 1974). The production of DIC was calculated as DIC production = DIC accumulation $+\mathrm{CaCO}_{3}$ precipitation.

The saturation of pore waters by rhodocrocite was calculated with the program PHREEQC using the thermodynamic constants of the database (Parkhurst 1995). Measured alkalinity and concentrations of DIC, $\mathrm{Ca}^{2+}$ and $\mathrm{Mn}^{2+}$ were included in the calculations. 
The penetration depth of oxygen, $h$, was estimated according to Revsbech et al. (1980): $h=2 D_{\mathrm{S}} C_{0} \phi / J$, where $D_{\mathrm{S}}$ is the diffusion coefficient in the sediment, $C_{0}$ is the oxygen concentration at the sediment surface, $\phi$ is the porosity, and $J$ the oxygen uptake rate. $D_{\mathrm{S}}$ was calculated according to Iversen \& Jørgensen (1993): $D_{\mathrm{S}}=D_{0} /[1+3(1-\phi)]$, where $D_{0}$ is the diffusion coefficient in sea water (taken from Schulz \& Zabel 2000): $D_{0}\left(\mathrm{O}_{2}\right)=1.2510^{-9} \mathrm{~m}^{2} \mathrm{~s}^{-1}\left(\right.$ at $\left.0^{\circ} \mathrm{C}\right)$.

The depth-integrated rates for Stn VIII in Table 2 were calculated from sediment incubations of the depth intervals 0 to 3 and 6 to $12 \mathrm{~cm}$.

\section{RESULTS}

\section{Pore water and solid phase chemistry}

The depth distribution of DIC, $\mathrm{NH}_{4}{ }^{+}, \mathrm{NO}_{3}{ }^{-}, \mathrm{Mn}^{2+}$ and $\mathrm{Fe}^{2+}$ in the pore water as well as solid phase $\mathrm{Mn}$ and $\mathrm{Fe}$ are shown in Fig. 2 for the 3 stations. DIC and $\mathrm{NH}_{4}{ }^{+}$concentrations increased with increasing depth from the overlying sea water into the sediment at all stations (Fig. 2A,D,G). Nitrate and nitrite concentrations in the sea water at all 3 stations were $\leq 17$ and $\leq 0.7 \mu \mathrm{M}$, respectively (Fig. 2B,E,H). Highest concentrations of nitrate were measured at 0 to $1 \mathrm{~cm}$ sediment depth at the $3 \mathrm{sta}-$ tions and concentrations decreased below a background level of $<2 \mu \mathrm{M}$ below $6 \mathrm{~cm}$ at Stn VIII and $3 \mathrm{~cm}$ at Stns X and XII. At the depths where nitrate concentrations decreased, soluble $\mathrm{Mn}^{2+}$ concentrations started to increase to maximum concentrations of $>75 \mu \mathrm{M}$ (Fig. 2B,E,H). $\mathrm{Fe}^{2+}$ in the pore water was mostly below detection at $\mathrm{Stn}$ $\mathrm{X}$ (Fig. 2E). $\mathrm{Fe}^{2+}$ concentrations at Stns VIII and XII were low $(<20 \mu \mathrm{M})$ and its distribution similar to that of $\mathrm{Mn}^{2+}$ (Fig. 2B,H). The extractable Mn and Fe(III) contents of the sediments were high, with concentrations of $\geq 60 \mu \mathrm{mol} \mathrm{cm} \mathrm{cm}^{-3} \mathrm{Mn}$ and $\geq 108 \mu \mathrm{mol} \mathrm{cm}{ }^{-3} \mathrm{Fe}$ (III) at all stations (Fig. 2C,F,I). Mn and Fe(III) were enriched at the surface at Stns X and XII, whereas at Stn VIII highest concentrations occurred between 4 and $8 \mathrm{~cm}$ depth. At Stn VIII, Fe(III) was depleted at $12 \mathrm{~cm}$ and $\mathrm{Mn}$ was pre-

Table 2. Depth-integrated rates of dissolved inorganic carbon (DIC) and $\mathrm{NH}_{4}{ }^{+}$production and sulfate reduction $\left(\mathrm{mmol} \mathrm{m}{ }^{-2}\right.$ $\mathrm{d}^{-1}$ ) and percentage $\mathrm{Mn} / \mathrm{Fe}$ reduction in anoxic bag incubations at 0 to $10 \mathrm{~cm}$ Stns VIII, X and XII. Mn/Fe reduction calculated from sulfate-independent DIC production rates as percent anaerobic carbon oxidation

\begin{tabular}{lccc|}
\hline Rate measured & VIII & $\mathrm{X}$ & $\mathrm{XII}$ \\
\hline DIC production & 2.0 & 1.5 & 4.3 \\
$\mathrm{NH}_{4}{ }^{+}$production & 0.12 & 0.20 & 0.46 \\
Sulfate reduction & $<0.1$ & $<0.1$ & 0.67 \\
Mn/Fe reduction $(\%)$ & $>90$ & $>87$ & 69 \\
\hline
\end{tabular}

sent from the surface to $>20 \mathrm{~cm}$ depth. In contrast, at Stns $\mathrm{X}$ and XII, Mn was depleted at shallower depths in the sediment compared to Fe(III) which reached down to 8 and $6 \mathrm{~cm}$, respectively. At all stations the sulfide concentration in the pore water was below the detection limit of $1 \mu \mathrm{M}$ and the sulfate concentration stayed constant over 0 to $20 \mathrm{~cm}$ depth. The elemental sulfur content at Stn XII peaked $\left(0.26 \mu \mathrm{mol} \mathrm{cm}{ }^{-3}\right)$ at $12 \mathrm{~cm}$ (Fig. 3A), whereas it was below detection at the other 2 stations. The total organic nitrogen and carbon contents of the sediments were similar for all 3 stations, with 0.17 to $0.18 \%$ organic nitrogen and 1.41 to $1.46 \%$ organic carbon (Table 1 ).

\section{Oxygen consumption and sulfate reduction rates of whole cores}

The oxygen uptake rates of the sediments were lowest at Stn X and highest at Stn XII (Table 1). Based on these rates, the oxygen penetration depths were calculated according to Revsbech et al. (1980) to be 1.8, 2.4 and $1.1 \mathrm{~cm}$ for Stns VIII, X and XII, respectively. Sulfate reduction rates were below our detection limit of $1 \mathrm{nmol} \mathrm{cm} \mathrm{c}^{-3} \mathrm{~d}^{-1}$ at 0 to $20 \mathrm{~cm}$ depth in the cores of Stns VIII and X. At Stn XII, sulfate reduction was below detection in the top $3 \mathrm{~cm}$ and increased to a maximum at 4 to $15 \mathrm{~cm}$ depth (Fig. 3B).

\section{Anoxic bag incubations}

Carbonate precipitation

DIC concentrations in bag incubations are expected to increase linearly during constant degradation of organic carbon. In this study, linear increases of DIC concurrent with constant $\mathrm{Ca}^{2+}$ concentrations were measured only in the pore water of the 2 bags for Stn X from 0 to 1 and 1 to $2 \mathrm{~cm}$ depth, in the bag from 6 to $12 \mathrm{~cm}$ for Stn VIII, and in the 4 bags from 3 to $10 \mathrm{~cm}$ for Stn XII (data not shown). Decreasing or constant DIC concentrations, either right from the beginning or after an initial increase, were measured in all other bags (Stn VIII 0 to $3 \mathrm{~cm}$, Stn X between 2 and $10 \mathrm{~cm}$, Stn XII between 0 and $3 \mathrm{~cm}$ ). As an example, data for Stn XII are shown in Fig. 4A. Non-linear changes in DIC concentration were related to decreasing $\mathrm{Ca}^{2+}$ concentrations over time in the respective bags (Fig. 4B), indicating a precipitation of $\mathrm{CaCO}_{3}$. DIC accumulation rates were corrected for $\mathrm{CaCO}_{3}$ precipitation according to Thamdrup et al. (2000). $\mathrm{CaCO}_{3}$ precipitation, however, did not seem to account for the complete carbonate precipitation. Additional precipitation of carbonate with $\mathrm{Mn}^{2+}$ was indicated by supersaturation of pore waters with rhodocrocite in most bags (ion-activity 


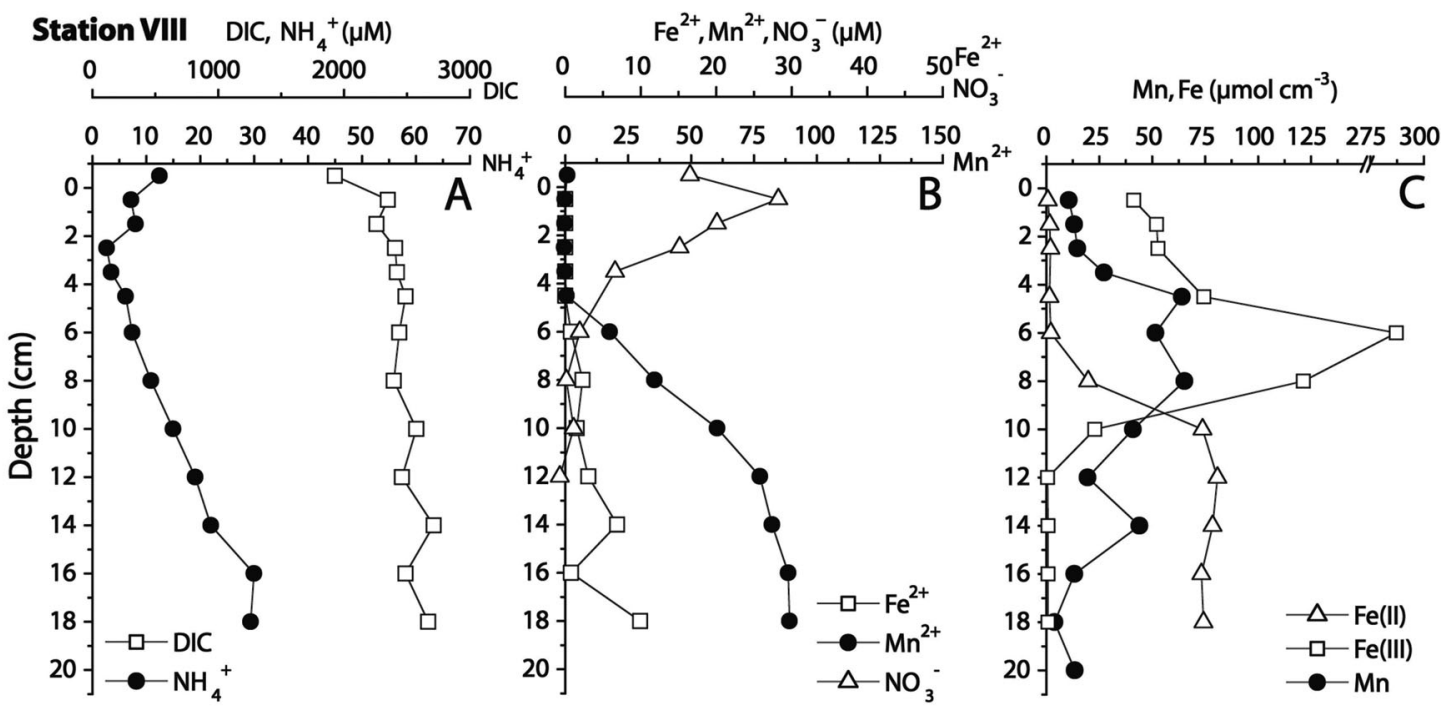

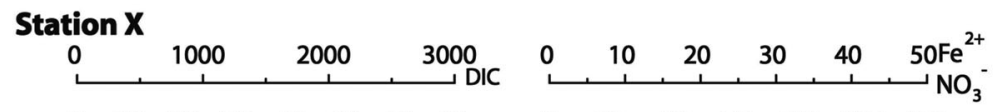

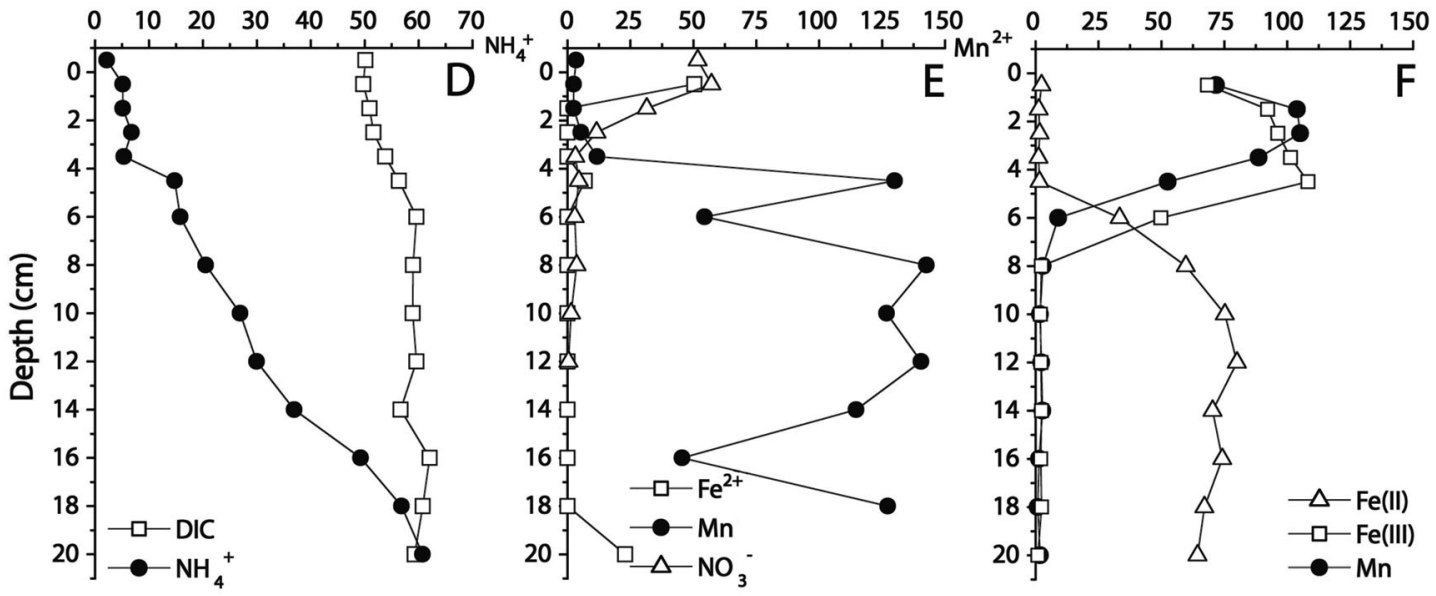

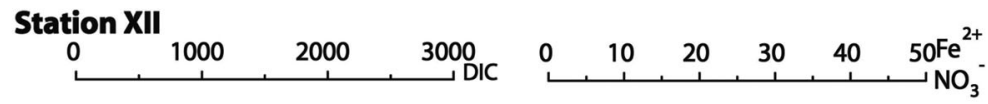

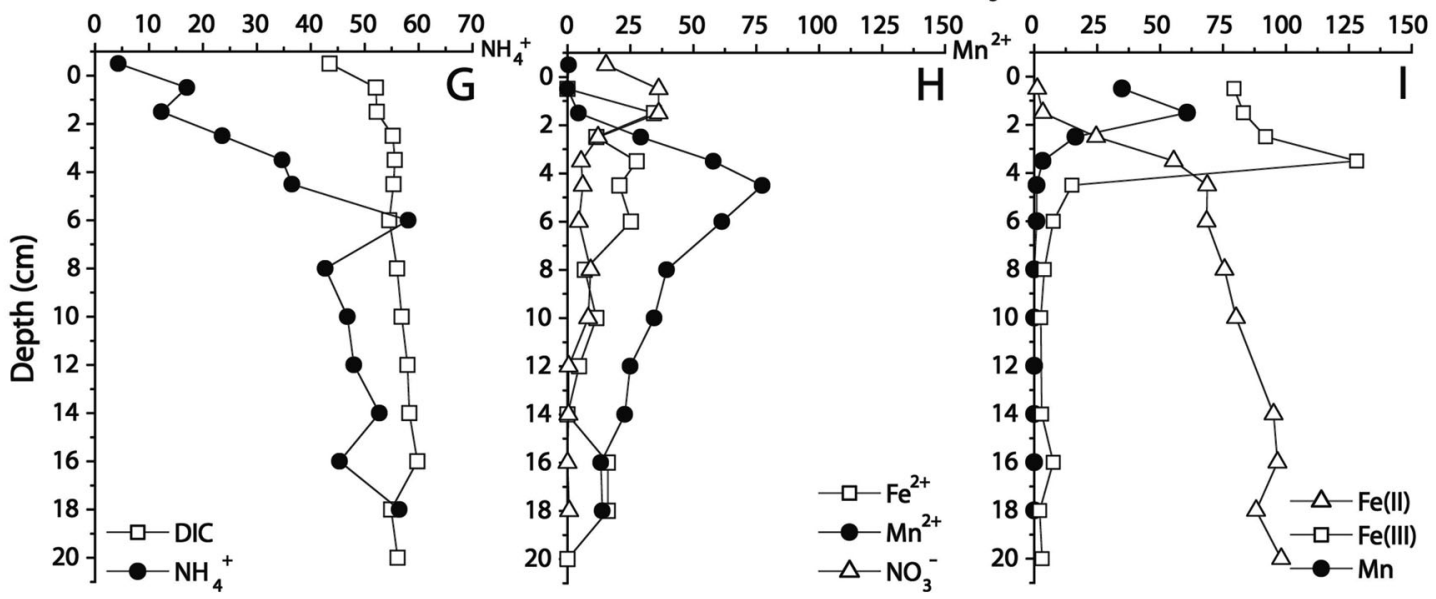

Fig. 2. Concentrations of pore water dissolved inorganic carbon (DIC), $\mathrm{NH}_{4}{ }^{+}, \mathrm{NO}_{3}{ }^{-}, \mathrm{Fe}^{2+}$ and $\mathrm{Mn}^{2+}$ and solid phase $\mathrm{Mn}$, Fe(III), and $\mathrm{Fe}(\mathrm{II})$ at Stns VIII, X and XII. Note change in scale on abscissa of (C) 


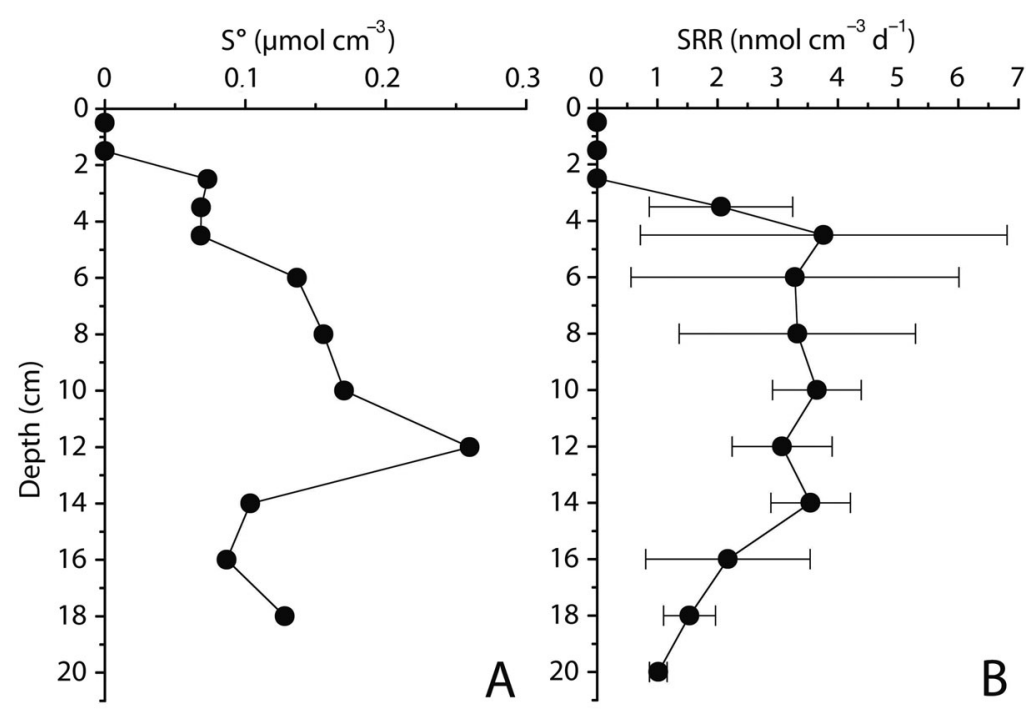

Fig. 3. (A) Solid phase $\mathrm{S}^{\circ}$ and (B) sulfate reduction rates (SRR) at Stn XII. Data are mean $\pm \mathrm{SD}$ of triplicate measurements. $\mathrm{S}^{\circ}$ concentrations and SSR were below detection at the other stations

products generally exceeded the solubility constant $>2$-fold) and decreasing $\mathrm{Mn}^{2+}$ accumulation rates towards the end of the incubations in the bags for Stn XII from 0 to $3 \mathrm{~cm}$ (Fig. 4C). Correction for $\mathrm{MnCO}_{3}$ precipitation was not done, as precipitation is dependent on the $\mathrm{Mn}^{2+}$ concentrations, which increased due to $\mathrm{Mn}$ reduction. Therefore, the corrected DIC production rates represent minimum rates (Thamdrup et al. 2000).

\section{DIC and $\mathrm{NH}_{4}^{+}$accumulation and sulfate reduction rates}

In general, rates of DIC and $\mathrm{NH}_{4}^{+}$accumulation in the pore water during anoxic sediment incubations decreased with increasing depth (Fig. 5). The depthintegrated rates were similar at Stns VIII and X, while rates were 2- to 4 -fold higher at Stn XII (Table 2). Sulfate reduction rates were below the detection limit at Stns VIII and X, similar to the whole core incubations. Sulfate reduction rates were also below detection between 0 and $3 \mathrm{~cm}$ at Stn XII, but increased with increasing depth below $3 \mathrm{~cm}$ (Fig. 6). Sulfate reduction rates were almost constant during the bag incubations, so average rates were used (data not shown). The depth-integrated sulfate reduction rate for bag incubations at Stn XII (Table 2) was 3-fold higher than in whole core incubations for the same depth interval (Table 1), probably due to a stimulation of carbon degradability by mixing of the sediment (Kostka et al. 1999, Arnosti et al. 2005). Assuming a stoichiometry of 2:1 mol of carbon oxidized (=DIC produced) to sulfate reduced (Thamdrup \& Canfield 1996), there was good agreement between DIC production based on sulfate reduction rates and the measured DIC production rates at 5 to $10 \mathrm{~cm}$ (Fig. 6). At 0 to $5 \mathrm{~cm}$, measured DIC production rates exceeded DIC production based on sulfate reduction. Thus, we conclude that electron acceptors other than sulfate were utilized for microbial carbon oxidation at Stn XII from the sediment surface down to $5 \mathrm{~cm}$ depth, and also at Stns VIII and X from 0 to $10 \mathrm{~cm}$, where no contribution of sulfate reduction to anaerobic carbon oxidation was detected.

$$
\mathrm{Mn}^{2+} \text { and } \mathrm{Fe}^{2+} \text { accumulation }
$$

Indications that microbial $\mathrm{Mn}$ and Fe reduction was an important respiratory process in the sediments were given by the accumulation of $\mathrm{Mn}^{2+}$ and $\mathrm{Fe}^{2+}$ in the pore water during bag incubations. $\mathrm{Mn}^{2+}$ accumulation in the bags scaled with solid Mn distribution at Stns VIII and XII, where rates were highest near the surface (Fig. 5A,C). In contrast, at Stn $\mathrm{X}, \mathrm{Mn}^{2+}$ concentrations at 0 to 1 and 1 to $2 \mathrm{~cm}$ sediment depth did not increase at all throughout incubation (Fig. 5B), although solid Mn was present. At 2 to $3 \mathrm{~cm}$ depth, $\mathrm{Mn}^{2+}$ started to accumulate after $15 \mathrm{~d}$ (data not shown), and in the bags from 3 to $10 \mathrm{~cm}$ the concentrations increased linearly throughout incubation. $\mathrm{Fe}^{2+}$ concentrations remained below background level $(\leq 16 \mu \mathrm{M})$ throughout incubation in all bags at Stns VIII and X. At Stn XII in the bag from 3 to $4 \mathrm{~cm}$ sediment depth, $\mathrm{Fe}^{2+}$ started to accumulate in the pore water halfway through the incubation period, and $\mathrm{Mn}^{2+}$ no longer accumulated (Fig. 7). Fe ${ }^{2+}$ concentrations also increased in the 2 bags from 4 to 5 and 5 to $7 \mathrm{~cm}$ towards the very end of incubation (Fig. 7), whereas $\mathrm{Fe}^{2+}$ concentrations remained low in the bags from 0 to 3 and 7 to $10 \mathrm{~cm}$ depth.

\section{DISCUSSION}

\section{Terminal electron accepting pathways in Arctic sediments}

\section{Aerobic respiration}

Total oxygen uptake rates were 1.5 to $3.5 \mathrm{mmol} \mathrm{m}^{-2}$ $\mathrm{d}^{-1}$ at the 3 stations northeast of Svalbard (Table 1). Similar rates of 1.9 to $4.1 \mathrm{mmol} \mathrm{m}^{-2} \mathrm{~d}^{-1}$ have been measured north and northeast of Svalbard, whereas higher 

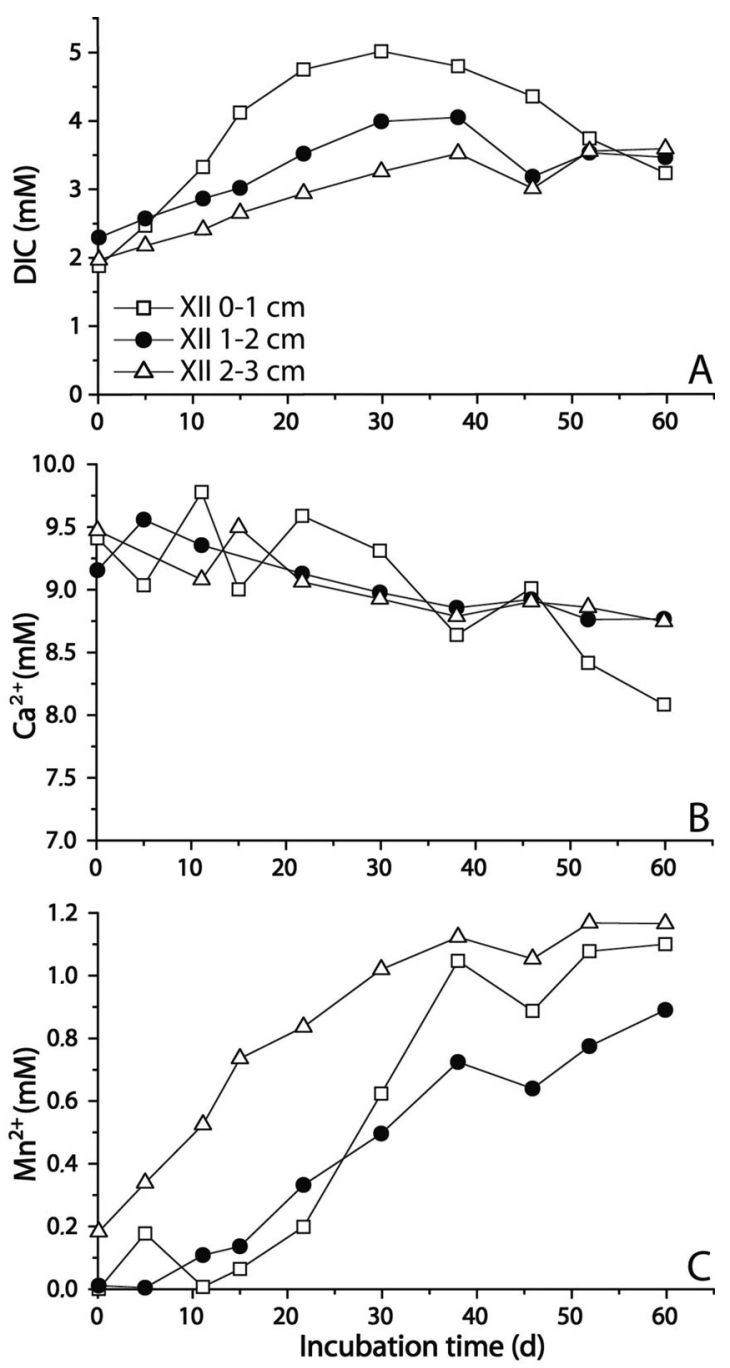

Fig. 4. Changes in pore water concentrations of DIC, $\mathrm{Ca}^{2+}$ and $\mathrm{Mn}^{2+}$ in sediment bags from $0-1,1-2$, and 2-3 cm depth at Stn XII during 2 mo anoxic incubation

rates ( 3.6 to $11.2 \mathrm{mmol} \mathrm{m}^{-2} \mathrm{~d}^{-1}$ ) have been determined in sediments along the south and west coasts (Hulth et al. 1994, Glud et al. 1998, Vandieken et al. 2006). The difference has been suggested to result from different water masses of Atlantic and Arctic origin determining the duration of the annual ice cover and, thus, the phytoplankton production (Hulth et al. 1994). Benthic oxygen consumption can also vary interannually as a response to the settling of fresh organic material from the water column due to ice melting (Rysgaard et al. 1998, Glud et al. 2003).

Hulth et al. (1994) measured oxygen penetration depths of 1.7 to $\geq 5.9 \mathrm{~cm}$ in sediments off the north and northeast coast of Svalbard. Based on oxygen uptake rates, we calculated oxygen penetration depths of 1.1 to $2.4 \mathrm{~cm}$ for the sediments studied. The presence of oxygen in the surface sediments was also indicated by the pore water chemistry. Maximum concentrations of nitrate below the surface indicated a zone of nitrification that requires the presence of oxygen (Fig. 2B,E,H). The depletion of oxygen in the sediments was indicated by decreasing concentrations of nitrate, probably due to denitrification, and increasing concentrations of $\mathrm{Mn}^{2+}$ with depth (Fig. 2B,E,H). The calculated oxygen penetration depths of $2.4 \mathrm{~cm}$ for Stn $\mathrm{X}$ and $1.1 \mathrm{~cm}$ for Stn XII were in accordance with the depletion of nitrate and the accumulation of $\mathrm{Mn}^{2+}$ below 2 and $1 \mathrm{~cm}$ depth, respectively. For Stn VIII, the distribution of nitrate and $\mathrm{Mn}^{2+}$ in the pore water indicated the deepest penetration of oxygen of $\sim 4 \mathrm{~cm}$, whereas the calculated oxygen penetration depth was only $1.8 \mathrm{~cm}$. A deeper penetration of oxygen might result from active bioirrigation by polychaetes, which introduce oxygen into deeper sediment layers (Jørgensen et al. 2005) and might cause spatial heterogeneity of pore water constituents. Because nitrate reduction is in general of minor importance for the degradation of organic matter and accounted for only 2 to $3 \%$ of total carbon oxidation in fjord sediments of Svalbard (Kostka et al. 1999), oxic respiration was probably the most important process in the surface sediments of the 3 stations. We conclude that, although the anoxic bag incubations revealed a high potential for anaerobic respiration even in the surface sediments, aerobic respiration and to a lesser extent, denitrification were important for organic carbon oxidation in surface-sediment intervals of 1 to $4 \mathrm{~cm}$ at all 3 stations.

\section{Sulfate reduction}

At Stn XII, the contribution of sulfate reduction to anaerobic carbon oxidation during sediment bag incubations for 0 to $10 \mathrm{~cm}$ depth was $0.67 \mathrm{mmol} \mathrm{m}^{-2} \mathrm{~d}^{-1}$ or $31 \%$ (assuming a stoichiometry of 2:1 DIC produced to sulfate reduced) (Table 2). Although at Stns VIII and X sulfate reduction rates were below the detection limit, we assume that sulfate reduction occurs at these stations. As anaerobic carbon oxidation rates were low (Fig. 5A,B, Table 2), either the incubation time with the ${ }^{35} \mathrm{SO}_{4}{ }^{2-}$ tracer might have been too short or too little tracer had been injected to detect sulfate reduction. However, based on the detection limit, we calculated the maximum contribution of sulfate reduction to anaerobic carbon oxidation integrated over 0 to $10 \mathrm{~cm}$ sediment depth to be $<0.1 \mathrm{mmol} \mathrm{m}^{-2} \mathrm{~d}^{-1}$ or $<10 \%$ for Stn VIII, and $<0.1 \mathrm{mmol} \mathrm{m} \mathrm{m}^{-2} \mathrm{~d}^{-1}$ or $<13 \%$ for Stn $\mathrm{X}$ (Tables 1 \& 2).

A higher contribution of sulfate reduction might have been masked by biologically catalyzed re-oxidation of sulfide to $\mathrm{SO}_{4}{ }^{2-}$ concomitant with $\mathrm{Mn}$ reduction 


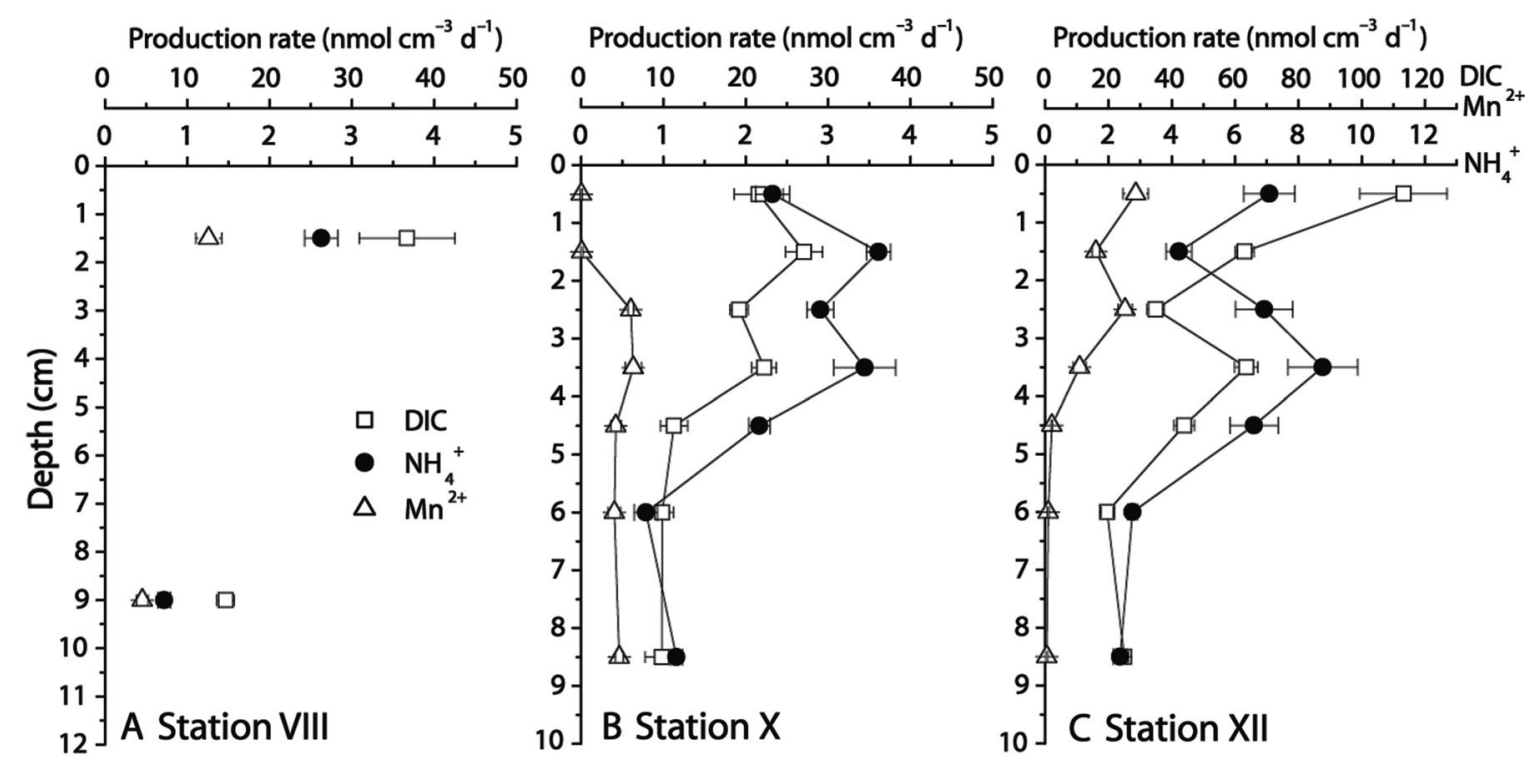

Fig. 5. Anaerobic DIC and $\mathrm{NH}_{4}{ }^{+}$mineralization rates and soluble $\mathrm{Mn}^{2+}$ accumulation rates at Stns VIII, X and XII. Data are mean $\pm \mathrm{SE}$ of linear regression of concentration over time. Note different production rate scales (abscissas)

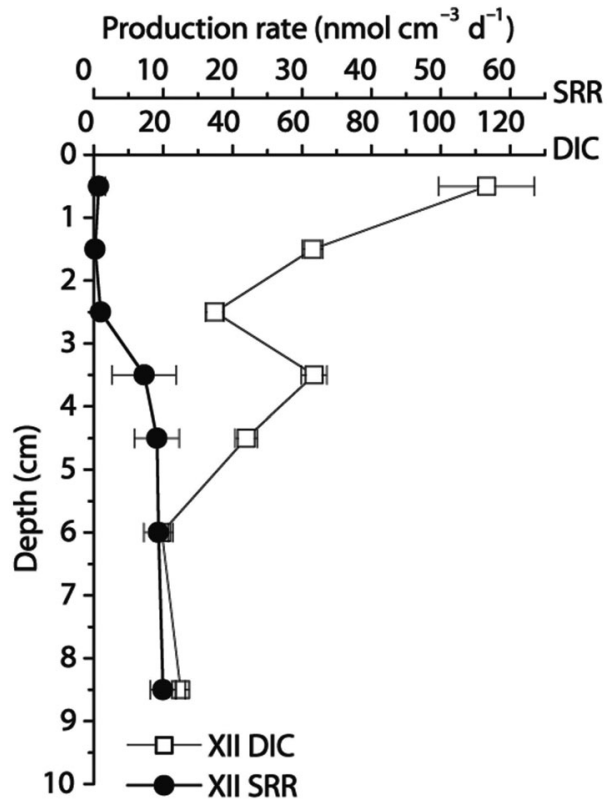

Fig. 6. Vertical profiles of anaerobic carbon mineralization at Stn XII, showing sulfate reduction rates (SRR) and DIC production rates. Data are means $\pm \mathrm{SE}$ of linear regression of DIC production and SD of SRR. Production rates plotted at ratio of 2:1 for DIC production to SRR

(Aller \& Rude 1988, King 1990). Thamdrup et al. (1993) suggested that in such experiments the chemical oxidation of $\mathrm{HS}^{-}$to $\mathrm{S}^{\circ}$ by $\mathrm{Mn}$ (IV) or $\mathrm{Fe}$ (III) is accompanied by microbial disproportionation of $\mathrm{S}^{\circ}$ to $\mathrm{SO}_{4}{ }^{2-}$ and $\mathrm{HS}^{-}$. However, the abundance of easily reducible $\mathrm{Mn}$ and Fe oxides should allow Mn- and Fe-reducing bac-

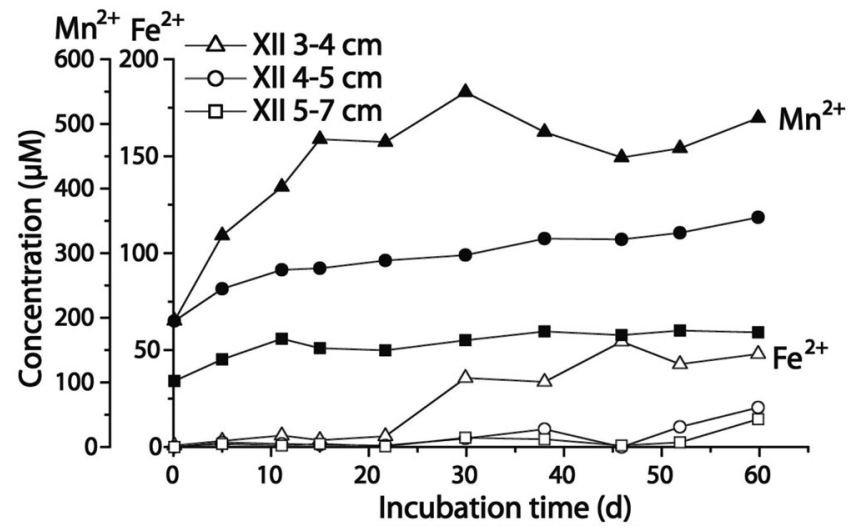

Fig. 7. Accumulation of $\mathrm{Mn}^{2+}$ (filled symbols) and $\mathrm{Fe}^{2+}$ (open symbols) in pore water during anoxic incubation of 3 sediment bags at $3-4,4-5$ and $5-7 \mathrm{~cm}$ in Stn XII

teria to exercise their thermodynamic advantage over sulfate reducers in competition for common substrates (Lovley \& Phillips 1987). We conclude that electron acceptors other than sulfate, most likely Mn(IV) and Fe(III), were the most important for anaerobic carbon oxidation at 0 to $10 \mathrm{~cm}$ sediment depth at Stns VIII and $\mathrm{X}$ and at 0 to $5 \mathrm{~cm}$ at Stn XII.

Mn and Fe reduction

The importance of Mn and Fe as microbial electron acceptors was supported by high contents of solid Mn and $\mathrm{Fe}(\mathrm{III})$ in the surface sediments of all stations from 
5 to $10 \mathrm{~cm}$ depth (Fig. 2C,F,I). Additionally, high concentrations of $\mathrm{Mn}^{2+}$ in the pore water indicated zones of $\mathrm{Mn}$ reduction and corresponded to increasing $\mathrm{Mn}^{2+}$ concentrations in most bags during sediment incubations (Figs. 2B,E,H, \& 5). Solid Mn was present from the sediment surface to a depth of $20 \mathrm{~cm}$ at Stn VIII (Fig. 2C) and dissolved $\mathrm{Mn}^{2+}$ accumulated in both bags at 0 to 3 and 6 to $12 \mathrm{~cm}$ depth during the incubation (Fig. 5A). Similarly, the accumulation of $\mathrm{Mn}^{2+}$ in the bags at 0 to $3 \mathrm{~cm}$ depth at Stn XII (Fig. 5C) was in agreement with solid $\mathrm{Mn}$ concentrations of 16 to $61 \mu \mathrm{mol} \mathrm{cm}{ }^{-3}$ (Fig. 2I). At Stn X, a correlation between solid $\mathrm{Mn}$ contents and accumulation rates of soluble $\mathrm{Mn}^{2+}$ was only determined for the 2 to $6 \mathrm{~cm}$ depth interval (Figs. 2F \& 5C).

Despite high concentrations of solid $\mathrm{Mn}, \mathrm{Mn}^{2+}$ did not accumulate in the pore water of the top $2 \mathrm{~cm}$. High rates of DIC and $\mathrm{NH}_{4}{ }^{+}$production indicated active microbial carbon oxidation (Fig. 5B), yet it was not clear which alternative electron acceptors other than Fe and Mn could have been used. Based on the oxygen consumption rate, the oxygen penetration depth, and the bottom-water concentration of oxygen $(334 \mu \mathrm{M})$, oxygen should have been depleted within less than $3 \mathrm{~d}$ incubation. Equivalent nitrate $(17 \mu \mathrm{M})$ and nitrite concentrations $(0.4 \mu \mathrm{M})$ were low, and probably were depleted fast. The lack of another obvious electron acceptor responsible for the continuous DIC and $\mathrm{NH}_{4}{ }^{+}$ production leads us to conclude that $\mathrm{Mn}$ reduction was also active at 0 to $2 \mathrm{~cm}$ but that the $\mathrm{Mn}^{2+}$ produced was totally adsorbed. Similar results were found in Skagerrak sediments of Denmark, where the lack of $\mathrm{Mn}^{2+}$ liberation in bag incubations of surface sediments was observed for 2 stations, whereas at a third station $\mathrm{Mn}^{2+}$ accumulated in the top sediment at high rates (Canfield et al. 1993b). Adsorption experiments showed that dissolved $\mathrm{Mn}^{2+}$ could be completely adsorbed onto sediments containing high concentrations of Mn oxide with oxidation levels of 3.6 to 3.8 (Murray et al. 1984, Canfield et al. 1993b). It was assumed that $\mathrm{Mn}^{2+}$ adsorbed on surface sites of Mn oxides and could only accumulate after these sites had been saturated. Based on such experiments, Canfield et al. (1993b) suggested that the surface sediment on which $\mathrm{Mn}^{2+}$ did not accumulate differed in capacity for adsorption of $\mathrm{Mn}^{2+}$ from the sediment of the third station, where $\mathrm{Mn}^{2+}$ accumulated and where the oxidation level of Mn oxides was probably less than 3.6 to 3.8. Correspondingly, we propose that the surface sediment from 0 to $2 \mathrm{~cm}$ depth at Stn X contained oxidized Mn oxides, whose surface completely adsorbed the $\mathrm{Mn}^{2+}$ produced during the incubation. Initial complete adsorption was also indicated for the bag from the underlying sediment (2 to $3 \mathrm{~cm}$ ), in which $\mathrm{Mn}^{2+}$ started to accumulate after $15 \mathrm{~d}$ incubation (data not shown).
At 6 to $10 \mathrm{~cm}$ depth, $\mathrm{Mn}^{2+}$ accumulated in the pore water, even though the Mn content was low $(<10 \mu \mathrm{mol}$ $\mathrm{Cm}^{-3}$ ) (Fig. 2F). In contrast to the profile in Fig. 2F, the Mn content of the bags from 6 to $10 \mathrm{~cm}$ depth at Stn X was $\geq 20 \mu \mathrm{mol} \mathrm{cm}{ }^{-3}$ (data not shown). This difference is probably due to local heterogeneity and the fact that sediment from 10 cores was pooled for the bag incubations. In Black Sea sediments, Mn concentrations above $\sim 10 \mu \mathrm{mol} \mathrm{cm} \mathrm{cm}^{-3}$ led to inhibition of sulfate reduction by microbial Mn reduction (Thamdrup et al. 2000). Thus, with Mn concentrations of $\geq 20 \mu \mathrm{mol} \mathrm{cm}^{-3}$ between 0 and $10 \mathrm{~cm}$ depth at Stn X, Mn was probably the most important electron acceptor.

Fe(III) was present at all stations and, except at Stn VIII, penetrated deeper into the sediment than Mn (Fig. 2C,F,I). However, $\mathrm{Fe}^{2+}$ did not accumulate during incubations in most bags. Heterotrophic Fe(III) reduction in the presence of Mn oxide might be masked by re-oxidation of produced $\mathrm{Fe}^{2+}$ by $\mathrm{Mn}(\mathrm{IV})$ (Lovley \& Phillips 1988, Myers \& Nealson 1988). Correspondingly, we could not exclude simultaneous microbial $\mathrm{Mn}$ and Fe reduction in the presence of high concentrations of solid Mn at the 3 stations.

At Stn XII at 3 to $4 \mathrm{~cm}$, high Fe(III) concentrations of $128 \mu \mathrm{mol} \mathrm{cm}{ }^{-3}$ and low Mn concentrations of $3 \mu \mathrm{mol}$ $\mathrm{cm}^{-3}$ probably limited microbial $\mathrm{Mn}$ reduction and favored Fe reduction in this zone. We suggest that produced $\mathrm{Fe}^{2+}$ first was abiotically oxidized by $\mathrm{Mn}(\mathrm{IV})$, which resulted in $\mathrm{Mn}^{2+}$ accumulation during the first half of the incubation (Fig. 7). After complete Mn(IV) reduction by $\mathrm{Fe}(\mathrm{II}), \mathrm{Fe}^{2+}$ could accumulate during the second half of the incubation. Similar observations have been made in pure-culture experiments (Myers \& Nealson 1988). In the 2 bags at 4 to 5 and 5 to $7 \mathrm{~cm}$, the accumulation of $\mathrm{Fe}^{2+}$ was also detected towards the very end of incubation (Fig. 7) but, with decreasing Fe(III) concentration, sulfate reduction became the dominating respiration pathway (Fig. 6). Altogether, Mn was probably the sole anaerobic terminal electron acceptor in the surface sediment at Stn XII, whereas below $3 \mathrm{~cm}$ a transition from microbial $\mathrm{Mn}$ to Fe reduction occurred. Fe and sulfate reduction concurred at 3 to $5 \mathrm{~cm}$ and at 5 to $10 \mathrm{~cm}$ sulfate was the sole important electron acceptor.

$\mathrm{Mn}^{2+}$ and $\mathrm{Fe}^{2+}$ liberation rates might indicate these to be the dominating respiration pathways, yet, as other reactions such as precipitation, adsorption and chemical oxidation occur simultaneously, metal reduction rates are usually underestimated (Canfield et al. 1993b, Thamdrup \& Canfield 1996, Glud et al. 2000, Thamdrup et al. 2000, Jensen et al. 2003). The rates of dissimilatory $\mathrm{Mn}$ and Fe reduction can be calculated by subtraction of DIC production based on sulfate reduction from the total DIC production, where the excess of carbon oxidation can be attributed to $\mathrm{Mn}$ 
and/or Fe reduction (Thamdrup 2000). Accordingly, at Stn VIII we attributed $>90 \%$, at Stn X $>87 \%$, and at Stn XII $69 \%$ of anaerobic carbon oxidation to microbial $\mathrm{Mn}$ and $\mathrm{Fe}$ reduction for an interval of 0 to $10 \mathrm{~cm}$ (Table 2).

It is likely that in situ Mn and Fe reduction in the surface sediments is suppressed through the presence of oxygen and nitrate. The abundance of oxygen and nitrate in surface sediments is important for the Mnand Fe-cycles, as they reoxidize the reduced $\mathrm{Mn}$ and Fe. Calculations for Danish coastal sediments showed that $\mathrm{Mn}$ and Fe atoms are recycled 100 to 300 times before their ultimate burial (Canfield et al. 1993b, Thamdrup et al. 1994). The maintenance of $\mathrm{Mn}$ and Fe reduction in the suboxic zone is dependent on mixing processes (Aller 1990, Canfield et al. 1993b, Thamdrup et al. 1994). Bioturbation enables the downward transport of organic matter and Mn and Fe oxides as well as upward transport of Fe(II) and Mn(II) for re-oxidation by oxygen, nitrate and, in the case of Fe(II), by Mn(IV) and the formation of new oxides. We observed the highest abundance of polychaetes and polychaete tubes at Stn XII, indicating bioturbation, which correlates with the highest rates of carbon oxidation and fastest turnover of $\mathrm{Mn}$ and Fe at 0 to $5 \mathrm{~cm}$.

In the zone where oxygen and nitrate are depleted, high concentrations of $\mathrm{Mn}$ and Fe(III) were present in the 3 sediments so that microbial $\mathrm{Mn}$ and Fe reduction in situ were the dominating respiratory pathways. The zone of $\mathrm{Mn}$ and Fe reduction was indicated by porewater concentrations of $\mathrm{Mn}^{2+}$ and $\mathrm{Fe}^{2+}$ (Fig. 2). In most marine shelf sediments, dissimilatory $\mathrm{Mn}$ reduction is insignificant for the oxidation of carbon because of low Mn oxide contents and a shallow depth distribution (Thamdrup 2000). Mn concentrations were low $\left(<4 \mu \mathrm{mol} \mathrm{cm}{ }^{-3}\right)$ or intermediate $\left(\sim 18 \mu \mathrm{mol} \mathrm{cm}{ }^{-3}\right)$ in sediments of Van Mijenfjorden and Smeerenburgfjorden on the west coast and in Storfjorden on the southeast coast of Svalbard (Kostka et al. 1999, Vandieken et al. 2006). Microbial Mn reduction was therefore assumed to be insignificant for carbon oxidation. Sediments with very high $\mathrm{Mn}$ oxide concentrations $(\geq 100 \mu \mathrm{mol}$ $\mathrm{cm}^{-3}$ ) are restricted to small areas of the world ocean such as the Panama Basin, where Mn is of hydrothermal origin, or the deep parts of the Skagerrak, where $\mathrm{Mn}$ released from more reducing sediments is trapped. At these sites, microbial $\mathrm{Mn}$ reduction was shown to account for more than $90 \%$ of the mineralization and could be detected as deep as $10 \mathrm{~cm}$ in the sediment (Aller 1990, Canfield et al. 1993b). The relatively high

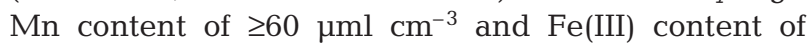
$\geq 108 \mu \mathrm{mol} \mathrm{cm} \mathrm{cm}^{-3}$ in sediment of the 3 stations off the northeast coast of Svalbard were related to the significance of dissimilatory $\mathrm{Mn}$ and Fe reduction for carbon oxidation (Table 2).
Our study supports the importance of metal reduction for carbon mineralization in permanently cold sediments. Previous studies determined that Fe reduction accounted for 0 to $26 \%$ of the total carbon oxidation in fjord sediments of the west coast of Svalbard (Kostka et al. 1999, Vandieken et al. 2006) and for 21 to $26 \%$ in sediments of east Greenland (Rysgaard et al. 1998, Glud et al. 2000). This is in agreement with contributions of 0 to $>50 \%$ of Fe reduction to total carbon mineralization found in a wide selection of coastal sediments (Thamdrup 2000).

\section{Rates and pathways of carbon oxidation in Arctic sediments}

Aerobic and anaerobic rates of carbon oxidation were highest for the middle station, Stn XII, and lowest at the southernmost station, Stn X (Tables 1 \& 2), indicating that the sediment of Stn XII is supplied annually with more organic carbon. A possible explanation is the semi-permanent polynya observed west and southwest of Kvitøya (Vinje \& Kvambekk 1991, FalkPetersen et al. 2000). This region is ice-free earlier than the surrounding area and probably has an earlier spring bloom and enhanced biomass production over the whole year (Strass \& Nöthig 1996, Falk-Petersen et al. 2000).

The retreat of the sea ice during late spring generally proceeds from 2 sides towards the northeast of Svalbard: along the east coast northwards and along the north coast eastwards (Falk-Petersen et al. 2000). Although Stn VIII was the deepest and northernmost station (Fig. 1 \& Table 1), higher aerobic and anaerobic carbon oxidation rates were measured compared to the southernmost station, X. As Stn VIII was situated in a trench that extends along the east coast of Nordaustlandet, we suggest that sediment might be transported from the surrounding slopes and northwards into the trench. This was also indicated by the sedimentation rates, which were twice as high at Stn VIII $(1.3 \mathrm{~mm}$

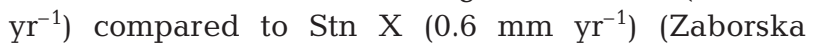
unpubl. data). Observations and satellite images covering several years have shown that in some years the area around Kong Karls Land (Stn X) is ice-covered longer than the area further north; this may restrict primary production. Thus, Stn X may be supplied with less organic material than the other 2 stations. In conclusion, primary production is probably higher at Stn VIII than at Stn X, and additional organic material may be transported to Stn VIII, becoming available for benthic oxidation and supporting higher mineralization rates in the north. However, the difference in carbon oxidation rates between the 2 stations was not very distinct. A variety of environmental differences e.g. ice 
coverage, currents and bottom topography make it difficult to define a single underlying cause.

Most studies of anaerobic benthic mineralization around Svalbard have been carried out in fjord sediments on the south and west coasts (Glud et al. 1998, Rysgaard et al. 1998, Sagemann et al. 1998, Thamdrup \& Fleischer 1998, Kostka et al. 1999, Finke 2003, Arnosti et al. 2005, Vandieken et al. 2006). Anaerobic carbon oxidation rates of sediment incubations (11 to $24 \mathrm{mmol} \mathrm{m} \mathrm{m}^{-2} \mathrm{~d}^{-1}$ ) and sulfate reduction rates (0.9 to $4.2 \mathrm{mmol} \mathrm{m}^{-2} \mathrm{~d}^{-1}$ ) in those fjord sediments are considerably higher than the rates measured in the sediments in this study (Tables 1 \& 2) (Sagemann et al. 1998, Kostka et al. 1999, Finke 2003, Vandieken et al. 2006). We suggest that temperature does not account for these differences, since the in situ temperature in sediments around Svalbard varies only from -1 to $+3^{\circ} \mathrm{C}$. Water depths of $\geq 300 \mathrm{~m}$ and the annually low primary production on the northeast coast (Wassmann \& Slagstad 1993, Sakshaug 1997) result in less organic carbon settling to the sea floor and may be responsible for the low rates of carbon oxidation in these sediments. In contrast, fjord sediments on the west coast receive a relatively large flux of organic carbon through primary productivity in the water column (Eilertsen et al. 1989, Hop et al. 2002). Therefore, we suggest that the supply and availability of organic carbon, and not low temperature, limits benthic activity on the northeast coast off Svalbard.

The organic carbon deposition to the sediment is an important factor regulating the importance of microbial Mn and Fe reduction (Thamdrup 2000). High carbon deposition favors sulfate reduction. The hydrogen sulfide produced reacts with $\mathrm{Mn}$ and $\mathrm{Fe}$, leaving less for microbial reduction. Intermediate organic carbon deposition increases the relative importance of suboxic respiration pathways (nitrate, $\mathrm{Mn}$ and Fe reduction) (Wang \& Van Cappellen 1996, Wijsman et al. 2002). Accordingly, microbial Fe reduction in the fjord sediments of Svalbard and Greenland, with relatively high primary production, contributed 0 to $26 \%$ to carbon oxidation (Rysgaard et al. 1998, Kostka et al. 1999, Glud et al. 2000, Vandieken et al. 2006). In sediments of the open Barents Sea with lower plankton production due to cold currents and long periods of ice coverage, we found that microbial $\mathrm{Mn}$ and Fe reduction were the most important anaerobic terminal electronaccepting pathways (69 to $>90 \%$ of anaerobic carbon oxidation).

In conclusion, the terminal electron accepting pathways in these Arctic sediments are regulated by carbon deposition to the sea floor, which is highly influenced by the duration of ice coverage. In sediments from shallow water depths and with long ice-free periods, such as fjord sediments on the south and west coasts of Svalbard, sulfate reduction will be the most important pathway for carbon mineralization. However, large parts of the Arctic Ocean are deeper and covered with ice during most or all of the year. Here, the suboxic pathways of $\mathrm{Mn}$ and Fe reduction will be important terminal electron accepting pathways.

A gradual retreat of the sea ice cover due to global warming will expectedly result in a preferential stimulation of sulfate reduction at the expense of metal reduction and a shallower suboxic zone. This will enhance the mobilization of Mn from the sediment and loss of $\mathrm{Mn}^{2+}$ to the water column. In the long term, this could result in a re-allocation of $\mathrm{Mn}$ in Arctic sediments from the continental shelf into deeper waters.

Acknowledgements. We thank P. Wassmann for organizing and leading the cruise as well as the captain, crew and scientific party of the RV 'Jan Mayen' for the successful expedition. Special thanks go to the 'benthic group' of CABANERA for help with sampling. Thanks to $C$. Wigand for providing the micro-optodes, and to S. Hessler at the University of Bremen for measuring samples by ICP-AES. We thank the University Centre on Svalbard (UNIS) for providing laboratory space. N. Finke and 3 anonymous reviewers are thanked for critical comments on the manuscript. This project was part of the Norwegian CABANERA Project (NFR 155936/700) and was funded by the Max Planck Society.

\section{LITERATURE CITED}

ACIA (Arctic Climate Impact Assessment) (2004) Impacts of a warming Arctic. Hassol SJ (ed). University of Cambridge, Cambridge

Aller RC (1990) Bioturbation and manganese cycling in hemipelagic sediments. Philos Trans R Soc Lond A 331: $51-68$

Aller RC, Rude PD (1988) Complete oxidation of solid phase sulfides by manganese and bacteria in anoxic marine sediments. Geochim Cosmochim Acta 52:751-765

Anderson PJ, Piatt JF (1999) Community reorganization in the Gulf of Alaska following ocean climate regime shift. Mar Ecol Prog Ser 189:117-123

Arnosti C, Jørgensen BB, Sagemann J, Thamdrup B (1998) Temperature dependence of microbial degradation of organic matter in marine sediments: polysaccharide hydrolysis, oxygen consumption, and sulfate reduction. Mar Ecol Prog Ser 165:59-70

Arnosti C, Finke N, Larsen O, Ghobrial S (2005) Anoxic carbon degradation in Arctic sediments: microbial transformations of complex substrates. Geochim Cosmochim Acta 69:2309-2320

Braman RS, Hendrix SA (1989) Nanogram nitrite and nitrate determination in environmental and biological materials by Vanadium(III) reduction with chemi-luminescence detection. Anal Chem 61:2715-2718

Canfield DE (1989) Reactive iron in marine sediments. Geochim Cosmochim Acta 53:619-632

Canfield DE, Jørgensen BB, Fossing H, Glud R and 6 others (1993a) Pathways of organic carbon oxidation in three continental margin sediments. Mar Geol 113:27-40 
Canfield DE, Thamdrup B, Hansen JW (1993b) The anaerobic degradation of organic matter in Danish coastal sediments: iron reduction, manganese reduction, and sulfate reduction. Geochim Cosmochim Acta 57:3867-3883

Cline JD (1969) Spectrophotometric determination of hydrogen sulfide in natural waters. Limnol Oceanogr 14: $454-458$

Eilertsen HC, Taasen JP, Weslawski JM (1989) Phytoplankton studies in the fjords of West Spitzbergen: physical environment and production in spring and summer. J Plankton Res 11:1245-1260

Falk-Petersen S, Hop H, Budgell WP, Hegset EN and 5 others (2000) Physical and ecological processes in the marginal ice zone of the northern Barents Sea during the summer melt period. J Mar Syst 27:131-159

Finke N (2003) The role of volatile fatty acids and hydrogen in the degradation of organic matter in marine sediments. $\mathrm{PhD}$ dissertation, University of Bremen, Bremen

Glud RN, Holby O, Hoffmann F, Canfield DE (1998) Benthic mineralization and exchange in Arctic sediments (Svalbard, Norway). Mar Ecol Prog Ser 173:237-251

Glud RN, Risgaard-Petersen N, Thamdrup B, Fossing H, Rysgaard S (2000) Benthic carbon mineralization in a highArctic sound (Young Sound, NE Greenland). Mar Ecol Progr Ser 206:59-71

Glud RN, Gundersen JK, Røy H, Jørgensen BB (2003) Seasonal dynamics of benthic $\mathrm{O}_{2}$ uptake in a semienclosed bay: importance of diffusion and faunal activity. Limnol Oceanogr 48:1265-1276

Grasshoff K, Kremling K, Ehrhardt M (1999) Methods of seawater analysis. Wiley-VCH Verlag, Weinheim

Hall POJ, Aller RC (1992) Rapid, small-volume, flow injection analysis $\Sigma \mathrm{CO}_{2}$ and $\mathrm{NH}_{4}{ }^{+}$in marine and freshwaters. Limnol Oceanogr 37:1113-1119

Hebbeln D, Wefer G (1991) Effects of ice coverage and icerafted material on sedimentation in the Fram Strait. Nature 350:409-411

Holst G, Glud RN, Kühl M, Klimant I (1997) A microoptode array for fine-scale measurement of oxygen distribution. Sensor Actuator B 38-39:122-129

Hop H, Pearson T, Hegseth EN, Kovacs KM and 26 others (2002) The marine ecosystem of Kongsjforden, Svalbard. Polar Res 21:167-208

Hulth S, Blackburn TH, Hall POJ (1994) Arctic sediments (Svalbard): consumption and microdistribution of oxygen. Mar Chem 46:293-316

Hulth S, Hall POJ, Blackburn TH, Landén A (1996) Arctic sediments (Svalbard): pore water and solid phase distribution of C, N, P and Si. Polar Biol 16:447-462

Iversen N, Jørgensen BB (1993) Diffusion coefficient of sulfate and methane in marine sediments: influence of porosity. Geochim Cosmochim Acta 57:571-578

Jensen MM, Thamdrup B, Rysgaard S, Holmer M, Fossing H (2003) Rates and regulation of microbial iron reduction in sediments of the Baltic-North Sea transition. Biogeochemistry 65:295-317

Jørgensen BB (1978) A comparison of methods for the quantification of bacterial sulfate reduction in coastal marine sediments. I. Measurement with radiotracer techniques. Geomicrobiol J 1:11-27

Jørgensen BB, Glud RN, Holby O (2005) Oxygen distribution and bioirrigation in Arctic fjord sediments (Svalbard, Barents Sea). Mar Ecol Prog Ser 292:85-95

Kallmeyer J, Ferdelman TG, Weber A, Fossing H, Jørgensen BB (2004) A cold chromium distillation procedure for radiolabeled sulfide applied to sulfate reduction measurements. Limnol Oceanogr Methods 2:171-180
King GM (1990) Effects of added manganic and ferric oxides on sulfate reduction and sulfide oxidation in intertidal sediments. FEMS Microbiol Ecol 73:131-138

Kostka JE, Thamdrup B, Glud RN, Canfield DE (1999) Rates and pathways of carbon oxidation in permanently cold Arctic sediments. Mar Ecol Prog Ser 180:7-21

Li YH, Gregory S (1974) Diffusion of ions in seawater and in deep-sea sediments. Geochim Cosmochim Acta 38: 703-714

Lovley DR, Phillips EJP (1987) Competitive mechanisms for inhibition of sulfate reduction and methane production in the zone of ferric iron reduction in sediments. Appl Environ Microbiol 53:2636-2641

Lovley DR, Phillips EJP (1988) Manganese inhibition of microbial iron reduction in anaerobic sediments. Geomicrobiol J 6:145-155

McGowan JA, Cayan DR, Dorman LM (1998) Climate-ocean variability and ecosystem response in the northeast Pacific. Science 281:210-217

Murray JW, Balistrieri LS, Paul B (1984) The oxidation state of manganese in marine sediments and ferromanganese nodules. Geochim Cosmochim Acta 48:1237-1247

Myers CR, Nealson KH (1988) Microbial reduction of manganese oxides: Interactions with iron and sulfur. Geochim Cosmochim Acta 52:2727-2732

Parkhurst DL (1995) User guide to PHREEQC - a computer program for speciation, reaction-path, advective transport, and inverse geochemical calculations. Water Resour Investig Rep US, Geol Surv 95-4227

Revsbech NP, Jørgensen BB, Blackburn TH (1980) Oxygen in the sea bottom measured with a microelectrode. Science 207:1355-1356

Rysgaard S, Thamdrup B, Risgaard-Petersen N, Fossing H, Berg P, Christensen PB, Dalsgaard T (1998) Seasonal carbon and nutrient mineralization in a high-Arctic coastal marine sediment, Young Sound, Northeast Greenland. Mar Ecol Prog Ser 175:261-276

Sagemann J, Jørgensen BB, Greef O (1998) Temperature dependence and rates of sulfate reduction in cold sediments of Svalbard, Arctic Ocean. Geomicrobiol J 15: 85-100

Sakshaug E (1997) Biomass and productivity distribution and their variability in the Barents Sea. ICES J Mar Sci 54: $341-350$

Schulz HD, Zabel M (2000) Marine geochemistry. SpringerVerlag, Berlin

Stookey LL (1970) Ferrozine-a new spectrophotometric reagent for iron. Anal Chem 42:779-781

Strass VH, Nöthig EM (1996) Seasonal shifts in ice edge phytoplankton blooms in the Barents Sea related to the water column stability. Polar Biol 16:409-422

Thamdrup B (2000) Bacterial manganese and iron reduction in aquatic sediments. Adv Microb Ecol 16:41-84

Thamdrup B, Canfield DE (1996) Pathways of carbon oxidation in continental margin sediments off central Chile. Limnol Oceanogr 41:1629-1650

Thamdrup B, Fleischer S (1998) Temperature dependence of oxygen respiration, nitrogen mineralization, and nitrification in Arctic sediments. Aquat Microb Ecol 15: 191-199

Thamdrup B, Finster K, Hansen JW, Bak F (1993) Bacterial disproportionation of elemental sulfur coupled to chemical reduction of iron or manganese. Appl Environ Microbiol 59:101-108

Thamdrup B, Glud RN, Hansen JW (1994) Manganese oxidation and in situ manganese fluxes from a coastal sediment. Geochim Cosmochim Acta 58:2563-2570 
Thamdrup B, Rosselló-Mora R, Amann R (2000) Microbial manganese and sulfate reduction in Black Sea shelf sediments. Appl Environ Microbiol 66:2888-2897

Vandieken V, Finke N, Jørgensen BB (2006) Pathways of carbon oxidation in an Arctic fjord sediment (Svalbard) and isolation of psychrophilic and psychrotolerant Fe(III)reducing bacteria. Mar Ecol Prog Ser 322:29-41

Vinje T, Kvambekk ÅS (1991) Barents Sea drift ice characteristics. Polar Res 10:59-68

Wang Y, Van Cappellen P (1996) A multicomponent reactive transport model of early diagenesis: application to redox cycling in coastal marine sediments. Geochim Cosmochim

Editorial responsibility: Howard I. Browman (Associate Editor-in-Chief), Storebø, Norway
Acta 60:2993-3014

Wassmann P, Slagstad D (1993) Seasonal and annual dynamics of particulate carbon flux in the Barents Sea. Polar Biol $13: 363-372$

Wijsman JWM, Herman PM, Middelburg JJ, Soetaert K (2002) A model for early diagenetic processes in sediments of the continental shelf of the Black Sea. Estuar Coast Shelf Sci 54:403-421

Zopfi J, Ferdelman TG, Fossing H (2004) Distribution and fate of sulfur intermediates - sulfite, tetrathionate, thiosulfate, and elemental sulfur - in marine sediments. Geol Soc Am Spec Pap 379:97-116

Submitted: September 8, 2005; Accepted: January 12, 2006 Proofs received from author(s): September 4, 2006 